\title{
The Relationship Between School Burnout and School Engagement: The Mediating Role of Attitude Toward Learning
}

\author{
Mustafa Yüksel Erdogdu \\ Faculty of Education, Istanbul Sabahattin Zaim University
}

\section{Abstract}

The main aim of the present study is to examine the mediating role of attitude toward learning in the relationship between school burnout and school engagement. This study was conducted on 471 high school students. The participants completed the School Burnout Scale, School Engagement Scale, and Scale of Attitudes Toward Learning. Data derived from the regression analysis show that school engagement and attitude toward learning were predicted negatively and significantly by school burnout. School engagement was predicted positively by attitude toward learning. Furthermore, attitude toward learning was determined to mediate the relationship between school burnout and school engagement partially. Findings indicate that practices which would diminish school burnout play important roles in school engagement and attitudes towards learning.

Key words: attitude toward learning, school burnout, school engagement, regression.

\section{Introduction - School Burnout}

Burnout is a negative emotion and is defined as physical and emotional exhaustion, desperation, loss of idealism, reduced personal accomplishment, feeling of failure (Maslach \& Jackson, 1981; Cherniss, 1980; Maslach \& Zimbardo, 1982). It is observed as emotional exhaustion, depersonalization and reduced personal accomplishment (Maslach \& Jackson, 1981; Maslach et al., 2001; Yazıc1 \& Avc1, 2011).

The first and most important phase of burnout is emotional exhaustion. This dimension is followed by other dimensions (depersonalization and reduced personal accomplishment). Emotional exhaustion is related to physical exhaustion, anxiety, 
insomnia and drug use, self-effacement in interpersonal relationships, a poor relationship between spouses and/or children, etc. Besides, emotional exhaustion is defined as one of the tension concepts including chronic, common and effective features of work experience and indicates the individual stress dimension of burnout (Gaines \& Jermier, 1983). A person feels emotionally worn-out and is observed to have exhaustion and low energy (Cordes \& Dougherty, 1993). Depersonalization represents the interpersonal dimension of burnout (Maslach, Schaufeli, \& Leiter, 2001), and it emerges as using despising language toward people, categorizing people, employers' treating their employees as if they were objects, working under harsh conditions, expecting mischief from people continuously, and therefore, keeping their distance (Boylu, 2012; Tevrüz, 1996; Leiter \& Maslach, 1988). A depersonalized individual minimizes his/ her contact and interaction with others and forms a buffer zone emotionally (Gezer, 2008). Reduced personal accomplishment means the following: "A person tends to view oneself negatively" (Maslach et al., 2001; Maslach \& Zimbardo, 1982). A person thinks that he/she is not successful at work and feels dissatisfied. Therefore, he/she feels guilty thinking that he/she is not making progress and instead is regressing (\$̧ıklar \& Tunalı, 2012; Tuğrul \& Çelik, 2002).

School burnout is defined as students' feeling of burnout as a result of high expectations of the education system, alienation from studying and resting, depersonalization, negative feelings such as dissatisfaction in the academic field (Schaufeli, 2002), stress, and emotional, cognitive and physical burnout of students (Aypay, 2011). According to Seçer (2015), the main signs of school burnout are exhaustion due to academic demands, indifference to school activities and homework, feeling of inadequacy for lessons, students' doubting their talents, academic failure, absenteeism, communicative problems with their peers and teachers.

In a study carried out by Aypay \& Eryllmaz (2011a), a negative correlation was determined between school burnout and loss of motivation. Subjective well-being is negatively affected especially as burnout stemming from family and loss of motivation toward school increases. In another study conducted by Aypay \& Eryllmaz (2011b), a significant negative correlation was found between motivation for participation in lessons and school burnout. As the loss of motivation toward school and burnout levels due to assignments increase, motivation for participation in lessons decreases. In a study carried out by McCarthy et al. (1990), stress caused by learning, i.e. having to study a lot of courses, and other psychological disorders were determined to be associated with emotional exhaustion, depersonalization tendency, and low academic achievement. A study conducted by Seçer (2015) on high school students observed that academic motivation decreases as the sub-dimensions of school burnout, namely emotional exhaustion, depersonalization, and reduced personal accomplishment, increase. In another study, it is pointed out that ordinary activities in lessons disturb students and after a while, it causes burnout. Furthermore, absenteeism, low motivation for lessons, and school dropouts increase (Meier \& Schmeck, 1985). As a result, school 
burnout does not only affect academic success negatively but also decreases the selfefficiency of learners and increases their stress levels (Zhang et al., 2005). There are also consequences such as becoming exhausted due to academic activities in addition to developing a negative attitude towards school activities (Morgan \& De Bruin, 2010).

\section{Learning and Attitude Toward Learning}

Learning is defined as the ability to adjust to changes using neural plasticity or as the increase in the number of synapses between the neurons (Wortock, 2002; Thomas, 2001; Chudler, 2005). According to another definition, learning represents a comparatively permanent change in behavior due to experience. It does not occur due to disease, fatigue or side effects of medications (Hergenhahn, 1988; Driscoll, 1994; Mayer, 1992; Shuell, 1986). Cognitive psychologists focus on the change in knowledge during learning and consider learning as internal cognitive activities (Schwartz \& Reisberg, 1991), whereas behaviorists emphasize the importance of the environment (Schunk, 2009; Hoy \& Miskel, 2010). Learning affects people in many ways and helps people adjust to the changing world. Adjusting to rapid changes in technology and science is, beyond doubt, related to individuals' attitude toward innovations. A study conducted by Pierce, Stacey \& Barkatsas (2007) shows that students' feelings, thoughts, and interests in learning a behavior or a subject affect their future behaviors. Individuals with positive attitudes display positive behaviors in relation to the subject, have high school engagement and make more effort to learn. In studies carried out by Duarte (2007) and Özden (2009), students display better performances in learning if they have a positive attitude. Students with a more positive attitude toward learning exhibit higher levels of success, and these learners choose the teaching profession with more motivation (Aktürk, 2012).

\section{School Engagement}

Jimerson et al. (2003) define school engagement as positive feelings about education, a sense of belonging to the school environment, and a positive relationship between school personnel and other students. In accordance with Sillins \& Mulford (2004), school engagement is students' perception of their teachers' attitude, relationship with their friends, and perception of how they are going to use their current knowledge in the future. According to Sinclair et al. (2001), participation in activities, scoring high in exams, time spent on assignments, and success are accepted as indicators of engagement.

Cernkovich and Giordano (1992) assert that there are four sub-dimensions of school engagement. These are "School Engagement" which means students' feelings for school and feeling safe at school, "Attachment to School Personnel" which means attachment to the principal, teacher and other personnel at school, "School Responsibility" which means participation in school activities and the importance of school in students' lives, and "Participation in School Activities" which means participating in school 
activities behaviorally. School engagement is described as one's sincere devotion to school and joy of school, which is important for academic development (Fredricks et al., 2004). As the commitment to school increases, levels of negative behaviors such as drug abuse and similar addictions, cheating in exams (Catalano et al., 2004; Morton, 2004; Finn \& Frone, 2004), and school dropout decrease (Audas \& Willms, 2002; McMahon et al., 2008).

Students who are engaged in school ask questions in class, talk to teachers, spend more time on learning or do more homework, participate in in-class activities (Finn \& Voelkl, 1993), have high academic achievement, participate in extracurricular activities, are more careful about attendance and socialize more with people (Klem \& Connell, 2004).

When studies on school engagement are taken into consideration, it can be observed that these studies focus on the correlation between school engagement and demographic variables (Cernkovich \& Giordano, 1992; Simons-Morton et al., 1999; McNeely at al., 2002; Eith, 2005), school engagement and attachment to a teacher (Murray \& Greenberg, 2000; Murray \& Grenberg, 2001), school engagement and problem behaviors (Bonny et al., 2000; Simons-Morton et al., 1999). Students with high levels of devotion display more motivation for participating in learning activities (Leitwood \& Jantzi, 2000; Jennings, 2003) and show more academic success (Klem \& Connell, 2004; Wang \& Holcombe, 2010; Conchas, 2001).

\section{The Mediating Role of Attitude Toward Learning}

Attitude toward learning, which is accepted as willingness to learn, curiosity for learning, and an effort to become successful, ar thought to increase students' school engagement and therefore decrease school burnout. A study conducted by Pierce et al. (2007) revealed that, if they have positive attitudes toward learning, it can be said that students are more willing to study and are more engaged in school. Students with high school burnout levels are less willing to learn (Yang, 2004), more prone to drop out of school (Bask \& Salmelo-Aro, 2012), become disinterested in school due to high levels of school burnout (Zhang et al., 2007), and are less motivated for lessons (Aypay \& Eryllmaz, 2011). There are some researches revealing that students who are successful and have a high motivation for learning have low levels of school burnout; and students who have low levels of school burnout have high levels of school attachment (Wang, et al.,2015; Pilkauskaite et al., 2011 ). There is no doubt that positive feelings towards learning is an important indicator of academic success. In other words, students who are academically successful are expected to have a positive attitude towards learning. In a study by Schaufeli et al. (2002), academic performance was negatively correlated with school burnout and academic performance was positively associated with school commitment. Another study shows that school burnout stems from negative attitudes towards learning, school and feelings of inadequacy (Lee et al., 2010).

It can be said that the research findings examining the relationships between the variables related to school burnout, learning-oriented attitude and adherence to 
school are evaluated as a whole. Furthermore, if the burnout level if the burnout level of school is low, the positive attitude towards learning will increase and this will contribute positively to the level of school adherence. The main purpose of the present study is to analyze the mediating role of attitude toward learning in the relationship between school burnout and school engagement. The basic hypotheses of this study are given below.

Hypothesis 1 School burnout is negatively related to attitude toward learning.

Hypothesis 2 School burnout is negatively related to school engagement.

Hypothesis 3 Attitude toward learning is positively related to school engagement.

Hypothesis 4 Attitude toward learning mediates the relation between school burnout and school engagement.

\section{Methods \\ Participants}

The study was conducted on 471 students studying at high schools in Küçükçekmecel Istanbul. The distribution of participants according to gender was as follows, 318 (68 $\%)$ were female students, while $153(32 \%)$ of them were male students. With respect to grade in high school, 95 (20\%) of the participants were freshman, 93 (20\%) of them were sophomore, 121 (26\%) of them were junior, and 162 (34\%) of them were senior students. Students' ages ranged between 13 and 18 years, and GPA scores ranged from 2.48 to 3.85. The mean age of the participants is 15,81 .

\section{Measures}

The School Bonding Scale (Cernkovich \& Giordano, 1992) was used to evaluate the participants' school engagement. The scale was developed by Cernkovich and Giordano (1992). It consists of 24 items and is a 5-point Likert-type scale adapted into Turkish by Can (2008). The positive items "Totally agree" are scored 5 points, while the negative items "Totally disagree" are scored 1 point. The other items are scored 4,3 , and 2 points. The $1^{\text {st }}, 2^{\text {nd }}, 5^{\text {th }}, 8^{\text {th }}, 9^{\text {th }}$, and $10^{\text {th }}$ items which contain negative expressions are scored reversely and summed (Can, 2008: 34). Confirmatory factor analysis was conducted for the purpose of determining the construct validity of the scale. Thereafter, a covariance matrix was prepared, and LISREL 8.8 was used. Finally, the Goodness of Fit Index (GFI), Normed Fit Index (NFI) $=0.92$, Comparative Fit Index $(\mathrm{CFI})=0.91$, and Root Mean Square Error of Approximation $(\mathrm{RMSEA})=0.076$ were obtained. The researcher calculated McDonald's omega reliability coefficient of the sub-dimensions one by one for the purpose of determining the coefficiency of the School Bonding Scale and eliminated those which were under .50 and completed the adaptation of the scale. As a result of this study, the School Bonding Scale obtained consists of 24 items and 6 factors (Can, 2008). The internal consistency reliability coefficient for this study was .91 . 
School Burnout Scale (Aypay, 2001). The School Burnout Scale is a 5-point Likerttype scale that consists of 26 items and 4 subtests. There are 4 sub-dimensions: burnout stem from school activities (12 items), burnout stem from family (5 items), feeling of insufficiency in school (4 items), and the lack of interest toward school (5 items). Confirmatory factor analysis was performed for the purpose of determining the construct validity of the scale. The KMO sampling adequacy coefficient was .93 , Bartlett's test $x^{2}$ value was 3831.14. As a result of the confirmatory factor analysis, the four-dimension model was found to be appropriate $(x 2=787.6, \mathrm{sd}=293, x 2 / \mathrm{sd}=2.68$, RMSEA =.07, NFI=.99, CFI=.91, IFI=1.00, RFI=.98, GFI=.94, AGFI=.91, SRMR=.015). The Cronbach's value of the subtests ranged from .76 to .92. In the current study, the internal consistency reliability coefficient for burnout stem from school activities is .83 , for burnout stem from family is .88 , for feeling of insufficiency in school is .74, and for the lack of interest toward school is .85 . The reliability coefficient for the whole scale is .80, and the Cronbach's alpha coefficient is .76.

Scale of Attitudes Toward Learning (Kara 2010). In order to determine participants' attitude toward learning, the Scale of Attitudes toward Learning was developed by Kara (2010). The scale consists of 40 items and 4 sub-dimensions which are the nature of learning ( 7 items), expectation ( 9 items), clarity ( 11 items), and anxiety (13 items). The Cronbach's alpha coefficient of the sub-dimensions in the scale ranges from .72 to .78. The results of the factor analysis of the scale are as follows: $\mathrm{KMO}=.79$, Bartlett's test of sphericity $=3101.363$, Cronbach's alpha $=.726$. The announced variance coefficient is above $50 \%$. The reliability coefficient of the scale obtained by the test-retest method is .87. The Cronbach's alpha coefficient of the current scale is .88 .

\section{Procedure and Data Analysis}

Permissions were obtained to apply the scales to the participants, and the purpose of the study was explained to the participants. The scale was administered to the volunteer participants in their classrooms. In total, 490 participants took part in the study, however 15 participants did not reply to the items as required, and 4 participants chose extremes in the scale and these ones were excluded. To study the correlation between points on the School Engagement Scale, Scale of Attitudes toward Learning, and School Burnout Scale, the Pearson product-moment correlation coefficient was used. To study the mediating role of attitude toward learning in the relationship between school engagement and school burnout, the hierarchical regression analysis applied by Baron \& Kenny (1986) was used. Analyses were performed using SPSS 22.0.

\section{Results}

\section{Descriptive Data and Inter-Correlations}

The correlation values of the used measurement tools, descriptive statistics and Cronbach's alpha values are given in Table 1.

When Table 1 is examined, it can be observed that there is a significant correlation between school engagement and attitude toward learning. There is a negatively 
significant correlation between school burnout, school engagement $(r=-.66)$, and attitude toward learning $(r=-.52)$. Furthermore, there is a positive relationship between attitude toward learning and school engagement $(r=.63)$.

\section{Testing the Mediating Role of Attitude Toward Learning in the Relationship Between School Burnout and School Engagement}

According to the stages of the mediation model, firstly, it was confirmed that school burnout and attitude toward learning were negatively associated $(\beta=.52, t=$ $-16.83, p=.000)$. Afterward, it was confirmed that attitude toward learning and school engagement were positively associated $(\beta=.62, t=22.10, p=.000)$. For the purpose of testing the final stage of the mediation model, a hierarchical regression analysis was performed. The results of the hierarchical regression analysis showed that school burnout was negatively related to school engagement $(\beta=-.66, t=-24.35, p<.01)$. Nevertheless, when attitude toward learning and school burnout were taken together in the regression analysis, the significance of the relationship between school burnout and school engagement $(\beta=-.46, t=-16.15, p<.01)$ decreased, but the association between school burnout and school engagement was still significant. According to Baron and Kenny (1986), the finding in question demonstrates a partial mediating role of attitude toward learning. According to the findings, it can be concluded that attitude toward learning partially mediates the relationship between school burnout and school engagement (Sobel $\mathrm{z}=12.52, \mathrm{p}<.000$ ). The results are given in Figure 1.

Table 1

Descriptive statistics, Cronbach's alpha coefficients, and inter-correlations of the variables

\begin{tabular}{lccc}
\hline Variables & 1 & 2 & 3 \\
\hline School Burnout & ----- & & \\
School Engagement & $-.66^{*}$ & ---- & \\
Attitude toward Learning & $-.52^{*}$ & $.63^{*}$ & ---- \\
Mean & 77.82 & 78.59 & 155.97 \\
Standard Deviation & 15.54 & 11.64 & 19.49 \\
Cronbach's $\alpha$ & .76 & .91 & .88 \\
\hline *p $<.01$ & & &
\end{tabular}

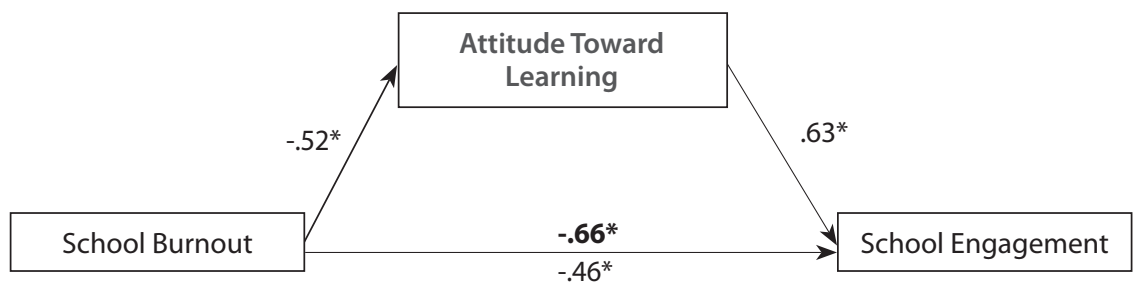

Figure 1. Regression coefficients for the relationship between school burnout and school engagement as mediated by attitude toward learning. The standardized regression coefficient between school burnout and school engagement, controlling for attitude toward learning, is in parentheses. ${ }^{*} p<.001$ 


\section{Discussion and Conclusion}

The aim of this study was to investigate the mediating role of attitude toward learning in the relationship between school burnout and school engagement. The findings of the study demonstrate that there is a negatively significant relationship between school burnout and school engagement and attitude toward learning playing a mediating role in the relationship between school burnout and school engagement, as expected. These results show that, when students' school burnout levels decrease school engagement levels increase; and that students' high levels of positive attitudes towards learning affect school engagement in a positive way.

The mentioned findings reveal the importance of attitude toward learning in enhancement of school engagement. As school burnout increases, school engagement decreases. Similarly, the research carried out on the association of school engagement and school burnout found out that there is a negative correlation between school burnout and school engagement (Schaufeli et al., 2002; Özdemir, 2015). The researches in the literature support the results of the study with similar findings. If students have a positive attitude toward learning, their school burnout level decreases and they become more successful academically (Murberg \& Bru, 2003; Bask \& SalmelaAro, 2013), they have positive feelings for school (Pilkauskaite at al., 2011), and they consider the school environment as more positive (Salmela et al., 2008). A study carried out by Schaufeli et al. (2002) determined that there is a negative relationship between academic performance and school burnout and there is a positive correlation between academic performance and school engagement. Hence, it can be understood that students spend more time studying, become more successful at school and, therefore, school engagement increases and school burnout level decreases if they have a positive attitude toward learning (Wang et al., 2015).

Attention is required in interpreting data obtained from the study. Firstly, it was ascertained that school burnout negatively predicts attitude toward learning, as it was assumed in the study. As school burnout level increases, attitude toward learning decreases and thus academic achievement is affected negatively (Schaufeli et al., 2002; Yang, 2004). Furthermore, students who experience school burnout also experience low self-competence (Guthrie et al., 1998; Esteve, 2008). School burnout increases academic stress (Murberg \& Bru, 2003), which influences the wellbeing of students negatively and as a result students appear unwilling in learning activities (Salmela \& Tynkkynen, 2012; Raiziene et al., 2014). Secondly, it was ascertained that attitude toward learning predicts school engagement positively. The finding that eagerness to learn and a positive attitude toward learning increase school engagement is parallel to other studies. They show that students with high school engagement are willing to learn and are academically more successful (Eith, 2005), have better relationships with their teachers (Murray \& Greenberg, 2000), take more responsibility at school (Jenkins, 1995) and take more part in school activities (Stewart, 2003). 
The limitations of the study should be considered while analyzing the data. Firstly, it is not correct to establish a cause-effect relationship since the study was not designed as an experimental study. Although structural equation modeling yields causality, it is not possible to make precise comments about causality between the variables because this research is a correlational study. This study was conducted on students from two different high schools within Küçükçekmece Municipality boundaries in Istanbul, who volunteered to participate in the study. Thus, it is important to replicate the study in different places and on similar student groups. Since the study aims to create a new model rather than test an existing model, the results have an explanatory quality. Therefore, the findings cannot be accepted as certain as long as the study is not replicated on different samples. The Scale of Attitudes toward Learning, School Burnout, and School Engagement Scales were used, and findings were obtained through the students' answers to the items, and qualitative measurement was not performed. The study revealed the mediating role of attitude toward learning in the relationship between school burnout and school engagement. Besides, there is a need for studies on other cognitive, affective and social variables which can play a mediating role in the relationship between school burnout and school engagement. Finally, counselors at school and experts are advised to do research to increase students' attitude toward learning, and they are also advised to implement psychoeducational programs which can decrease students' school burnout and increase their school engagement.

\section{References}

Aktürk, A. O. (2012). Öğretmen adaylarının öğrenmeye ilişkin tutumlarının öğretmenlik mesleğini tercih etme nedenlerine ve akademik başarılarına göre incelenmesi [Investigation of teacher candidates' attitudes towards learning according to reasons for choosing teaching profession and academic achievement]. Ahi Evran Üniversitesi Krrşehir Eğitim Fakültesi Dergisi, 13(3), 43-78.

Audas, R., \& Willms, J. D. (2002). Engagement and dropping out of school: A life-course perspective. Applied Research Branch, Human Resources Development Canada.

Aypay, A. (2011). İlköğretim ikinci kademe öğrencileri için okul tükenmişliği ölçeği Geçerlik ve güvenirlik çalışması [School burnout scale for primary school second graders. Validity and reliability study]. Kuram ve Uygulamalarda Eğitim Bilimleri Dergisi, 11(2), 511-527.

Aypay, A., \& Eryılmaz, E. (2011.a). Lise öğrencilerinin öznel iyi oluşları ve okul tükenmişliği arasındaki ilişkiler [Relations between subjective well-being of high school students and school burnout]. International Online Journal of Educational Sciences, 3(1), 181-199.

Aypay, A., \& Eryılmaz, E. (2011.b). Lise öğrencilerinin derse katılmaya motive olmaları ile okul tükenmişliği arasındaki ilişkinin incelenmesi [Examination of the relationship between high school students' motivation to attend classes and school burnout]. Mehmet Akif Ersoy Üniversitesi Eğitim Fakültesi Dergisi, 11(21), 26-44. 
Baron, R. M., \& Kenny, D. A. (1986). Moderator-mediator variables distinction in social psychological research: Conceptual, strategic, and statistical considerations. Journal of Personality and Social Psychology, 51(6), 1173-1182. https://doi.org/10.1037/0022$\underline{3514.51 .6 .1173}$

Bask, M., \& Salmelo-Aro, K. (2012). Burned out to drop out: Exploration of the relationship between school burnout and school dropout. European Journal of Psychology of Education, 28(2), 511-528. doi: 10.1007/s10212-012-0126-5. https:// doi.org/10.1007/s10212-012-0126-5

Boylu, A.Y. (2012). Adalet bakanlı̆̆ı’na bağlı kurumlarda çalışan personelin yaşam doyumu, iş doyumu ve mesleki tükenmişlik düzeylerinin cinsiyet ve hizmet süresi değişkenlerine göre incelenmesi [Examination of the life satisfaction, job satisfaction and occupational burnout levels of the personnel working in institutions affiliated to the Ministry of Justice according to the variables of gender and duration of service]. Adalet Dergisi, 44 (6), 123), 141.

Can, S. (2008). Ortaokul öğrencilerinin okula bağlılık düzeylerini bazı değişkenlere göre incelenmesi [Examination of secondary school students' attachment levels to the school by some variables]. Yayınlanmamış Yüksek Lisans Tezi, Ege Üniversitesi, İzmir.

Catalano, R. F., Oesterle, S., Fleming, C. B., \& Hawkins, J. D. (2004). The importance of bonding to school for healthy development: Findings from the Social Development Research Group. Journal of school health, 74(7), 252-261. https://doi.org/10.1111/j.1746-1561.2004. $\underline{\text { tb08281.x }}$

Cernkovich, S. A., \& Giardano, P.C. (1992). School bonding, race and delinquency. Criminology, 30(2), 361-291. https://doi.org/10.1111/j.1745-9125.1992.tb01105.x

Cherniss, C. (1980). Staff burnout, job stress in the human service. Beverly Hills, CA: Sage.

Chudler, E. H. (2005). Brain plasticity: What is it? Learning and memory. html 07 Ocak 2005, http://www. faculty. washington. edu/chudler/plast.

Conchas, G. (2001). Structuring failure and success: Understanding the variability in Latino school engagement. Harvard Educational Review, 71(3), 475-505. https://doi.org/10.17763/ haer.71.3.280w814v1603473k

Cordes, C.L., \& Dougherty. T.W. (1993). A Review and an Integration of research on job burnout. The Academy of Management Review, 18(4), 621-656. https://doi.org/10.5465/ amr.1993.9402210153

Driscoll, M.P. (1994). Psychology of learning for instruction. Allyn\&Bacon

Duarte, A. M. (2007). Conceptions of learning and approaches to learning in Portuguese students. Higher Education, 54(6), 781-794. https://doi.org/10.1007/s10734-006-9023-7

Eith, C. (2005). Delinquency, schools, and the social bond. New York, LFB Scholarly Publishing LLC.

Esteve, E. B. (2008). Well-being and performance in academic settings: The predicting role of self-efficacy. Unpublished doctoral dissertation, Universitat Jaume I, US, Spain.

Finn, J. D., \& Voelkl, K. E. (1993). School characteristics related to student engagement. The Journal of Negro Education, 62(3), 249-268. https://doi.org/10.2307/2295464

Finn, K. V., \& Frone, M. R. (2004). Academic performance and cheating: Moderating role of school identification and self-efficacy. The Journal of Educational Research, 97(3), 115-121. https://doi.org/10.3200/JOER.97.3.115-121 
Fredricks, J. A., Blumenfeld, P. C., \& Paris, A. H. (2004). School engagement: Potential of the concept, state of the evidence. Review of educational research, 74(1), 59-109. https://doi. org/10.3102/00346543074001059

Gaines J., \& Jermier J. (1983). Emotional Exhaustion in a High Stress Organization. Academy of Management Journal. 26(4), 567-586. https://doi.org/10.5465/255907

Gezer, E. (2008). Stres veren yaşam olaylarının, öğretim elemanlarının, depresyon ve tükenmişlik düzeylerine etkisi [Effects of stressful life events, teaching staff, depression and burnout levels]. Yayımlanmamış Doktora Tezi. Ankara: Gazi Üniversitesi Sağlık Bilimleri Enstitüsü.

Guthrie, E., Campbell, M., Black, D., Creed, F., Bagalkote, H., \& Shaw, C. (1998). Psychological stress and burnout in medical students: a five-year prospective longitudinal study. Journal of the Royal Society of Medicine, 91(5), 237-243. https://doi.org/10.1177/014107689809100502

Hergenhahn B. R. (1988). An Introduction to Theories of Learning(3.bask1). Prentice Hall. Hoy,W.K., \& Miskel, C.G.(2010). Eğitim Yönetimi. Nobel yayıncılık.

Jenkins, P. (1995). School delinquency and commitment. Sociology of Education, 63, 221-239. https://doi.org/10.2307/2112686

Jennings, G. (2003). An exploration of meaningful participation and caring relationships as contexts for school engagement. The California School Psychologist, 8(1), 43-51. https:// doi.org/10.1007/BF03340895

Klem, A. M., \& Connell, J. P. (2004). Relationships matter: Linking teacher support to student engagement and achievement. Journal of school health, 74(7), 262-273. https:// doi.org/10.1111/j.1746-1561.2004.tb08283.x

Klem, A. M., \& Connell, J. P. (2004). Relationships matter: Linking teacher support to student engagement and achievement. Journal of school health, 74(7), 262-273. https:// doi.org/10.1111/j.1746-1561.2004.tb08283.x

Lee, J., Puig, A., Kim, Y. B., Shin, H., Lee, J. H., \& Lee, S. M. (2010). Academic burnout profiles in Korean adolescents. Stress and Health, 26(5), 404-416. https://doi.org/10.1002/smi.1312

Leiter, M. P., \& Maslach, C. (1988). The Impact of interpersonal environment on burnout and organizational commitment. Journal of Organizational Behavior, 9(4), 297 308. https:// doi.org/10.1002/job.4030090402

Leithwood, K., \& Jantzi, D. (2000). Principal and Teacher Leadership Effects: A replication, School Leadership \& Management, 20(4), 415-434. https://doi.org/10.1080/713696963

Maslach, C., \& Jackson, S. E. (1981). The measurement of experienced burnout. Journal of organizational behavior, 2(2), 99-113. https://doi.org/10.1002/job.4030020205

Maslach, C., \& Zimbardo, P.G. (1982). Burnout-The Cost of Caring, Prentice-Hall, Inc., Englewood Cliffs.

Maslach, C., Schaufeli, W. B., \& Leiter, M. P. (2001). Job burnout. Annual review of psychology, 52(1), 397-422. https://doi.org/10.1146/annurev.psych.52.1.397

Mayer, R.E.(1982). Learning. In H. E. Mitzel (Ed.). Encyclopedia of Educational Research (pp.1040-1058). Free Pres.

McCarthy, M. E., Pretty, G. M., \& Catano, V. (1990). Psychological Sense of Community and Student Burnout. Journal of College Student Development, 31 (5), 211-216. 
McMahon, S. D., Parnes, A.L., Keys, C. B., \& Viola, J. J. (2008). School belonging among lowincome urban youth with disabilities: Testing a theoretical model. Psychology in the Schools, 45(5), 387- 401. https://doi.org/10.1002/pits.20304

McNeely, C.A., Nonnemaker, J. M., \& Blum, R. W. (2002). Promoting school connectedness: evidence from the national longitudinal study of adolescent health. Journal of School Health, 72(4), 138-146. https://doi.org/10.1111/j.1746-1561.2002.tb06533.x

Meier, S. T., \& Schmeck, R. R. (1985). The burned-out college student: A descriptive profile. Journal of College Student Personnel, 25(3), 63-69.

Morgan, B., \& De Bruin, K. (2010). The relationship between the big five personality traits and burnout in South African university students. South African Journal of Psychology, 40(2), 182-191. https://doi.org/10.1177/008124631004000208

Murberg, T. A., \& Bru, E. (2003). School related stress and psychosomatic symptoms among Norwegian adolescents. School Psychology International,25(3), 317-332. https://doi. org/10.1177/0143034304046904

Murray, C., \& Greenberg, M. (2000). Children's relationship with teachers and bonds with school: An investigation of patterns and correlates in middle childhood. Journal of School Psychology, 38(5), 423-445. https://doi.org/10.1016/S0022-4405(00)00034-0

Murray, C., \& Greenberg, M. (2001). Relationships with teachers and bonds with school: Social emotional adjustment correlates for children with and without disabilities. Psychology in the Schools, 38(1), 25-41. https://doi.org/10.1002/1520-6807(200101)38:1<25::AIDPITS4>3.0.CO;2-C

Özdemir, Y. (2015). Ortaokul öğrencilerinde okul tükenmişliği: Ödev, okula bağlılık ve akademik motivasyonun rolü [School burnout in secondary school students: The role of homework, school commitment and academic motivation]. Adnan Menderes Üniversitesi Eğitim Fakültesi Eğitim Bilimleri Dergisi, 6(1), 27-35.

Özden, M. (2009). An investigation of some factors affecting attitudes toward chemistry in university education. Essays in Education, Special Edition, 90-99.

Pierce, R., Stacey, K., \& Barkatsas, A. (2007). A scale for monitoring students' attitudes to learning mathematics with technology. Computers and Education, 48(2), 285-300. https:// doi.org/10.1016/j.compedu.2005.01.006

Pilkauskaite-Valickiene, R., Zukauskiene, R., \& Raiziene, S. (2011). The role of attachment to school and open classroom climate for discussion on adolescents' school-related burnout. Procedia-Social and Behavioral Sciences, 15, 637-641. https://doi.org/10.1016/j. $\underline{\text { sbspro.2011.03.155 }}$

Raiziene, S., Pilkauskaite-Volickiene, R., \& Zukouskiene, R. (2014). School burnout and subjective well-being: evidence from crosslagged relations in a 1 - year longitudinal sample. Procedia - Social and Behavioral Sciences, 116, 3254 - 3258. https://doi.org/10.1016/j. $\underline{\text { sbspro.2014.01.743 }}$

Salmela-Aro, K., Kiuru, N., Pietikäinen, M., \& Jokela, J. (2008). Does school matter? The role of school context in adolescents' school-related burnout. European Psychologist, 13(1), 1-13. https://doi.org/10.1027/1016-9040.13.1.12

Salmela-Aro, K., \& Tynkkynen, L. (2012). Gendered pathways in school burnout among adolescents. Journal of Adolescence, 35(4), 929-93. https://doi.org/10.1016/j.adolescence.2012.01.001 
Schaufeli, W. B. (2002). Burnout and engagement in university students: A National Study. Journal of Cross-Cultural Studies, 33(5), 464-481. https://doi.org/10.1177/0022022102033005003

Schaufeli, W. B., Martinez, I. M., Pinto, A. M., Salanova, M., \& Bakker, A. B. (2002). Burnout and engagement in university students a cross-national study. Journal of Cross-Cultural Psychology, 33(5), 464-481. https://doi.org/10.1177/0022022102033005003

Schwartz, B., \& Reisberg, D. (1991). Learning and Memory. New York: W.W. Nortonand Company.

Shuell, T.J.(1986). Cognitive Conceptions. Learning Review of Educational Research,56(4),411-436. https://doi.org/10.3102/00346543056004411

Simons-Morton, B. G., Crump, A. D., Haynie, D. L., \& Saylor, K. E. (1999). Student school bonding and adolescent problem behavior. Health Education Research, 14(1), 99-107. https://doi.org/10.1093/her/14.1.99

Simons-Morton, B. (2004). Prospective association of peer influence, school engagement, drinking expectancies, and parent expectations with drinking initiation among sixth graders. Addictive Behaviors, 29(2), 299-309. https://doi.org/10.1016/j.addbeh.2003.08.005

Sinclair, M. F., Hurley, C. M., Evelo, D. L., Christenson, S. L., \& Thurlow, M. L. (2001). Making connections that keep students coming to school. In R. Algozzine, \& P. Kay (Eds.), Preventing problem behaviors: A handbook of successful prevention strategies (pp. 162-182). Corwin Press.

Stewart, E. A. (2003). School social bonds, school climate, and school misbehavior: a multilevel analysis, Justice Quarterly, 20(3), 575-604. https://doi.org/10.1080/07418820300095621

Şıklar, E., \& Tunalı, D. (2012). Çalışanların Tükenmişlik Düzeylerinin İncelenmesi: Eskişehir Örneği [Examination of Burnout Levels of Employees: Eskişehir Example]. Dumlupınar Üniversitesi Sosyal Bilimler Dergisi, 33 (2), 75-86.

Tevrüz, S.(1996). Endüstri ve Örgüt Psikolojisi [Industrial and Organizational Psychology], Türk Psikologlar Derneği ve Kalite Derneği Ortak Yayıncılık.

Thomas, P. B. (2001). The implication of brain research in preparing young children to enter school ready to learn. The Florida Agricultural and Mechanical University College of Education.

Tuğrul, B., \& Çelik, E. (2002). Normal çocuklarla çalışan anaokulu öğretmenlerinde tükenmişlik [Burnout in kindergarten teachers working with normal children]. Pamukkale Üniversitesi Eğitim Fakültesi Dergisi, 12 (12), 1-11.

Wang, M., \& Holcombe, R. (2010). Adolescents' Perceptions of School Environment, Engagement, and Academic Achievement in Middle School, American Educational Journal Research, 47(3), 633-662. https://doi.org/10.3102/0002831209361209

Wang, M.T., Chow, A., Hofkens T., \& Salmela-Aro, K. (2015). The trajectories of student emotional engagement and school burnout with academic and psychological development: Findings from Finnish adolescents. Learning and Instruction. 36, 57-65.

Wortock, J.M.M. (2002). Brain based learning principles applied to the teaching of basic cardiac code to associate degree nursing students using the human patient simulator, Ph.D. Thesis, University of South Florida.

Wright, T.A., \& Douglas, G.B. (1997). The Contribution of Burnout to Work Performance. Journal of Organizational Behavior, 18(5), 491-499. https://doi.org/10.1002/(SICI)10991379(199709)18:5<491::AID-JOB804>3.0.CO;2-I 
Yang, H.J. (2004). Factors affecting student burnout and academic achievement in multiple enrollment programs in Taiwan's technical-vocational colleges. International Journal of Educational Development, 24(3), 283-301. https://doi.org/10.1016/j. ijedudev.2003.12.001

Yazıc1, K., \& Avc1, E. (2011). Sosyal bilgiler öğretmenlerinin mesleki tükenmişlik durumlarının çeşitli değişkenlere göre incelenmesi [Examination of social worker teachers' occupational burnout status according to various variables]. Pegem Eğitim ve Öğretim Dergisi, 1(4), 29-37. https://doi.org/10.14527/C1S4M4

Zhang, Y., Gan, Y., \& Cham, H. (2007). Perfectionism, academic burnout and engagement among Chinese college students: A structural equation modeling analysis. Personality and Individual Differences, 43(6), 1529-1540. https://doi.org/10.1016/j.paid.2007.04.010

Zhang, Y., Gan, Y., \& Cham, H. (2005). The reliability and validity of MBI-SS and academic characteristics affecting burnout. Chinese Journal of Clinical Psychology, 13(8), 383-385.

\section{Mustafa Yüksel Erdogdu}

Department of Psychological Counselling and Guidance Faculty of Education Istanbul Sabahattin Zaim University Halkalı Mahallesi, Halkalı Kampüsü Halkalı Caddesi, D:No:281 34303 Küçükçekmece/Istanbul, Turkey myerdogdu@gmail.com 


\section{Povezanost izgaranja u školi i angažiranosti u školi: posrednička uloga stava prema učenju}

\section{Sažetak}

Glavni cilj ovoga istraživanja je proučiti posredničku ulogu stava prema učenju u odnosu na izgaranje u školi i angažiranosti u školi. Ovo istraživanje provedeno je na 471 učeniku srednje škole. Ispitanici su popunili tri skale, odnosno skalu Izgaranje u školi, skalu Angažiranost u školi i skalu Stavovi prema učenju. Podatci dobiveni regresijskom analizom pokazuju da su angažiranost u školi i stav prema učenju negativno i značajno predviđeni stavom prema učenju. Stav prema učenju pozitivno predviđa angažiranost u školi. Nadalje, stav prema učenju doprinosi odnosu izgaranja u školi i djelomično angažmanu u školi. Rezultati pokazuju da postupci koji bi smanjili izgaranje u školi imaju veliku ulogu kod angažiranosti u školi i stavovima prema učenju.

Ključne riječi: angažiranost u školi; izgaranje u školi; regresija; stav prema učenju.

\section{Uvod - izgaranje u školi}

Izgaranje je negativna emocija i definira se kao fizička i emocionalna iscrpljenost, očajanje, gubitak idealizma, smanjeno osobno postignuće, osjećaj neuspjeha (Maslach i Jackson, 1981; Cherniss, 1980; Maslach i Zimbardo, 1982). Manifestira se kao emocionalna iscrpljenost, depersonalizacija i smanjeno osobno postignuće (Maslach i Jackson, 1981; Maslach i sur., 2001; Yazıc1 i Avc1, 2011).

Prva i najvažnija faza izgaranja je emocionalna iscrpljenost. Ovu dimenziju prate druge dimenzije (otuđenost i smanjeno osobno postignuće). Emocionalna iscrpljenost povezana je s fizičkom iscrpljenošću, anksioznošću, nesanicom i korištenjem lijekova, samozatajnošću u međuljudskim odnosima i lošim odnosom između supružnika i/ili djece itd. Nadalje, emocionalna iscrpljenost definira se kao jedan od oblika napetosti uključujući kronična, uobičajena i učinkovita obilježja radnoga iskustva i ukazuje na dimenziju izgaranja prema stresu pojedinca (Gaines i Jermier, 1983). Osoba je emocionalno istrošena, vidljivo iscrpljena, bez energije (Cordes i Dougherty, 1993). Otuđenost označava međuljudsku dimenziju izgaranja (Maslach, Schaufeli i Leiter, 2001) i pokazuje se kao korištenje prezirnog jezika prema ljudima, kategoriziranju ljudi, odnosu prema zaposlenicima kao prema stvarima, rad u teškim uvjetima, neprestano 
očekivanje zlobe kod ljudi i posljedično držanje ljudi na distanci (Boylu, 2012; Leiter i Maslach, 1988 Tevrüz, 1996). Otuđeni pojedinac minimizira svoj kontakt i interakciju $s$ drugima te stvara emocionalnu tampon-zonu (Gezer, 2008). Smanjeno osobno postignuće ima sljedeće značenje: „Osoba samu sebe često percipira u negativnom svijetlu" (Maslach i sur., 2001; Maslach i Zimbardo, 1982). Osoba misli da nije uspješna na poslu i osjeća se nezadovoljno, stoga ima osjećaj krivnje jer ne vidi napredak i u isto vrijeme nazaduje. (Şıklar i Tunalı, 2012; Tuğrul i Çelik, 2002).

Izgaranje u školi definira se kao učenikov osjećaj izgaranja zbog visokih očekivanja od obrazovnoga sustava, udaljavanje od učenja i odmaranja, otuđenost, negativni osjećaji poput nezadovoljstva u akademskom postignuću (Schaufeli, 2002), stres i emocionalno, kognitivno i fizičko izgaranje učenika (Aypay, 2011). Prema Seçer (2015), glavni znakovi školskoga izgaranja su iscrpljenost zbog akademskih očekivanja, ravnodušnost prema školskim aktivnostima i zadaći, osjećaj nedoraslosti za nastavu, sumnja u vlastite talente, akademski neuspjeh, odsutnost, problemi u komunikaciji s vršnjacima i nastavnicima.

U istraživanju koje su proveli Aypay i Eryllmaz (2011a) uočena je negativna korelacija između školskoga izgaranja i gubitka motivacije. Subjektivna dobrobit pod negativnim je utjecajem jer izgaranje proizlazi iz obitelji, a gubitak motivacije prema školi se povećava. U drugome istraživanju (Aypay i Eryılmaz, 2011b) značajna negativna korelacija uočena je između motivacije za sudjelovanjem u nastavi i školskim izgaranjem. Kako se gubitak motivacije prema školi i razine izgaranja zbog količine zadataka povećava, smanjuje se motivacija za sudjelovanjem u nastavi. Istraživanje koje su proveli McCarthy i sur. (1990) upućuje na to da je stres izazvan učenjem, brojem predmeta u školi i drugim psihološkim poremećajima povezan s emocionalnom iscrpljenošću, tendencijom prema otuđenosti i slabim akademskim uspjehom. Prema Seçer (2015) $\mathrm{i}$ istraživanju provedenom na srednjoškolcima, motivacija za školu smanjuje se kako se poddimenzije školskoga izgaranja poput emocionalne iscrpljenosti, otuđenosti i smanjenoga osobnog postignuća povećavaju. U drugome istraživanju ukazuje se na to da uobičajene aktivnosti tijekom nastave ometaju učenike i nakon nekog vremena uzrokuju izgaranje. Štoviše, povećava se odsutnost, niska motivacija na nastavnom satu te odustajanje od škole (Meier i Schmeck, 1985). Kao rezultat, školsko izgaranje ne utječe negativno samo na školsko postignuće nego smanjuje samoučinkovitost učenika i povećava njihove razine stresa (Zhang i sur., 2005). Tu su i posljedice poput iscrpljenosti od nastavnih aktivnosti kao i stvaranje negativnih stavova prema školskim aktivnostima (Morgan i De Bruin, 2010).

\section{Učenje i stav prema učenju}

Učenje se definira kao sposobnost prilagodbe promjenama koristeći neuralnu plastičnost ili kao povećanje broja sinapsi između neurona (Chudler, 2005; Thomas, 2001; Wortock, 2002). Prema drugoj definiciji, učenje predstavlja razmjerno stalnu promjenu u ponašanju uzrokovanu iskustvom. Ne događa se zbog bolesti, umora ili nuspojava različitih medikamenata (Driscoll, 1994; Hergenhahn, 1988; Mayer, 1992; 
Shuell, 1986). Kognitivni psiholozi usredotočuju se na promjene u znanju tijekom učenja i učenje vide kao unutarnje kognitivne aktivnosti (Schwartz i Reisberg, 1991), dok bihevioristi naglašavaju važnost okoline (Hoy i Miskel, 2010; Schunk, 2009). Učenje utječe na ljude na mnogo načina i pomaže ljudima prilagoditi se svijetu koji se mijenja. Prilagodba brzim promjenama u tehnologiji i znanosti nesumnjivo je povezana sa stavovima pojedinca prema inovacijama. Istraživanje koje su proveli Pierce, Stacey i Barkatsas (2007) pokazuje da osjećaji učenika, njihova razmišljanja i interesi tijekom učenja nekog ponašanja ili nastavnoga predmeta utječu na njihova buduća ponašanja. Pojedinci s pozitivnim stavovima pokazuju pozitivna ponašanja vezana uz nastavni predmet, sudjeluju u nastavi i ulažu više napora u učenje. $U$ istraživanjima koje su proveli Duarte (2007) i Özden (2009) učenici su pokazali bolja postignuća u učenju ako su imali pozitivne stavove. Učenici s pozitivnim stavovima prema učenju pokazali su više razine uspjeha i ti učenici s puno više motivacije odabiru učiteljsku profesiju (Aktürk, 2012).

\section{Angažiranost u školi}

Jimerson i sur. (2003) definiraju školski angažman kao pozitivne osjećaje o obrazovanju, osjećaj pripadnosti školskom okruženju i pozitivnom odnosu prema osoblju škole i drugim učenicima. U skladu s definicijom Sillins i Mulford (2004) školski angažman je učenikova percepcija stava učitelja, odnosa s prijateljima i percepcija toga kako će trenutačno znanje upotrijebiti u budućnosti. Prema Sinclair i sur. (2001) sudjelovanje u aktivnostima, visoki rezultati na ispitima, vrijeme provedeno radeći zadatke i uspjeh prihvaćeni su kao pokazatelji angažiranosti.

Cernkovich i Giordano (1992) tvrde da postoje četiri poddimenzije školskoga angažmana. To su „školski angažman“ što znači osjećaje učenika prema školi i osjećaj sigurnosti u školi, „privrženost osoblju škole“ što znači privrženost ravnatelju, učitelju i drugom osoblju, ,školska odgovornost“ što znači sudjelovanje u školskim aktivnostima i važnost koju škola ima u životu učenika te „sudjelovanje u školskim aktivnostima“ što podrazumijeva fizičko sudjelovanje u školskim aktivnostima. Školski angažman opisuje se kao iskrena predanost učenika školi i radost u školi što je važno za akademski razvoj (Fredricks i sur., 2004). Povećavanje obaveza prema školi dovodi do smanjivanja razine negativnih ponašanja poput zlouporabe droge i sličnih ovisnosti, varanje na ispitima (Catalano i sur., 2004; Finn i Frone, 2004; Morton, 2004) i prekidanje školovanje (Audas i Willms, 2002; McMahon i sur., 2008).

Učenici koji su angažirani postavljaju pitanja tijekom sata, razgovaraju s učiteljima, provode više vremena učeći ili radeći domaću zadaću, sudjeluju u razrednim aktivnostima (Finn i Voelkl, 1993), imaju visoka akademska postignuća, sudjeluju u izvannastavnim aktivnostima, vode računa o prisutnosti na nastavi te se više druže $s$ ljudima (Klem i Connell, 2004).

Kada se uzmu u obzir istraživanja vezana uz angažman u školi, može se primijetiti da su ta istraživanja usredotočena na korelaciju između angažmana u školi i demografskih varijabli (Cernkovich i Giordano, 1992; Eith, 2005; McNeely i sur., 2002; Simons- 
Morton i sur., 1999), angažmana u školi i privrženosti učitelju (Murray i Greenberg, 2000; Murray i Grenberg, 2001), angažmana u školi i problema u ponašanju (Bonny i sur., 2000; Simons-Morton i sur., 1999). Učenici s visokim razinama predanosti pokazuju više motivacije za sudjelovanjem u aktivnostima učenja (Leitwood i Jantzi, 2000; Jennings, 2003) i pokazuju veće akademsko postignuće (Klem i Connell, 2004; Wang i Holcombe, 2010; Conchas, 2001).

\section{Posrednička uloga stava prema učenju}

Mišljenja smo da stav prema učenju koji shvaćamo kao spremnost za učenjem, znatiželja za učenjem, napor uložen da bi se postigao uspjeh, povećava angažman u školi i posljedično tome smanjuje izgaranje u školi. Istraživanje koje su proveli Pierce i sur. (2007) pokazalo je da ukoliko učenici imaju pozitivne stavove prema učenju, utoliko imaju više želje za učenjem i više su angažirani u školi. Učenici s visokim razinama sagorijevanja manje su voljni učiti (Yang, 2004), skloni su odustajanju od škole (Bask i Salmelo-Aro, 2012), postaju nezainteresirani za školu upravo zbog visokih razina izgaranja (Zhang i sur., 2007) te su manje motivirani za nastavu (Aypay i Eryllmaz, 2011). Postoje neka istraživanja koja su pokazala da uspješni učenici imaju visoku motivaciju za učenjem i imaju nisku razinu izgaranja; učenici koji imaju niske razine izgaranja imaju visoka akademska postignuća u školi (Pilkauskaite i sur., 2011; Wang i sur., 2015). Nema sumnje da su pozitivni osjećaji prema učenju važan pokazatelj akademskoga postignuća. Drugim riječima, očekuje se da su akademski uspješni učenici oni koji imaju pozitivne stavove prema učenju. U istraživanju koje su proveli Schaufeli i sur. (2002), uspjeh u školi negativno je povezan s izgaranjem u školi i uspjeh u školi pozitivno je povezan s predanošću školi. Drugo istraživanje pokazalo je da izgaranje u školi proizlazi iz negativnih stavova prema učenju, školi i osjećajima nepodobnosti (Lee i sur., 2010).

Može se reći da su rezultati istraživanja koja proučavaju odnose između varijabli povezanih s izgaranjem u školi, stavom prema učenju i privrženost školi sagledana u cjelini. Stoga se može reći da ako je razina izgaranja u školi niska, povećat će se pozitivan stav prema učenju i to će pozitivno doprinijeti razini privrženosti školi. Svrha ovoga istraživanja je analizirati posredničku ulogu stava prema učenju u odnosu između izgaranja u školi i angažmana u školi. Osnovne hipoteze istraživanja su:

Hipoteza 1 Izgaranje u školi negativno je povezano sa stavom prema učenju.

Hipoteza 2 Izgaranje u školi negativno je povezano s angažmanom u školi.

Hipoteza 3 Stav prema učenju pozitivno je povezan s angažmanom u školi.

Hipoteza 4 Stav prema učenju posreduje u povezanosti između izgaranja u školi i angažmana u školi.

\section{Metode}

\section{Ispitanici}

Istraživanje je provedeno na 471 učenikom srednjih škola u Küçükçekmece/Istanbul. Distribucija ispitanika prema spolu bila je sljedeća: 318 (68 \%) učenica i $153(32 \%)$ 
učenika. S obzirom na razred koji pohađaju u srednjoj školi, 95 (20\%) ispitanika su učenici prvoga razreda, 93 (20\%) učenici drugoga razreda, 121 (26\%) učenici trećega razreda i $162(34 \%)$ su učenici četvrtoga razreda srednje škole. Dob učenika je između 13 i 18 godina, a njihov prosjek ocjena između 2,48 i 3,85. Srednja vrijednost za dob učenika je 15,81 .

\section{Instrumenti}

Za procjenu angažmana ispitanika u školi korištena je skala Povezanost sa školom (School Bonding Scale, Cernkovich \& Giordano, 1992). Skalu su razvili Cernkovich i Giordano (1992). Ona se sastoji od 24 čestice i koristi Likertovu skalu od 5 stupnjeva. Skalu je na turski jezik prilagodio Can (2008). Pozitivne čestice ,u potpunosti se slažem“ ostvaruju 5 bodova, dok negativne čestice „u potpunosti se ne slažem“ ostvaruju 1 bod. Druge čestice ostvaruju 4, 3 i 2 boda. Prva, druga, peta, osma i deseta čestica koje su negativne izjave boduju se obrnuto te se zbrajaju (Can, 2008: 34). Potvrdna faktorska analiza provedena je u svrhu određivanja valjanosti konstrukta ljestvice. Nakon toga pripremljena je kovarijantna matrica i korišten je LISREL 8.8. Konačno, dobiveni su i indeks prikladnosti modela (GFI) i indeks standardizirane prikladnosti (NFI) $=0,92$, indeks prikladnosti usporedbe $(\mathrm{CFI})=0,91$ te srednjokvadratna pogreška aproksimacije $($ RMSEA $)=0,076$. Izračunat je McDonald's omega pouzdanost koeficijenta pojedinačnih poddimenzija u svrhu određivanja koeficijenta skale Povezanost sa školom te je eliminirao one čiji su rezultati bili niži od .50 i na taj je način skala prilagođena. Kao rezultat dobivena je skala Povezanost sa školom koja se sastoji od 24 čestice i 6 faktora (Can, 2008). Koeficijent unutarnje pouzdanosti koeficijenta za ovo istraživanje bio je .91 .

Skala izgaranja u školi (School Burnout Scale, Aypay, 2001). Skala izgaranja u školi je Likertova skala od 5 stupnjeva koja se sastoji od 26 čestica i 4 podtesta. Četiri su poddimenzije: izgaranje koje proizlazi iz školskih aktivnosti (12 čestica), izgaranje koje proizlazi iz obitelji (5 čestica), osjećaj nedostatnosti u školi (4 čestice) i nedostatak interesa za školu ( 5 čestica). Potvrdna faktorska analiza provedena je u svrhu određivanja valjanosti konstrukta ljestvice. Koeficijent prikladnosti uzorka KMO bio je .93, Bartlettov test $x^{2}$ vrijednost bila je 3831,14. Kao rezultat potvrdne faktorske analize, model s četiri dimenzije bio je najprikladniji $(x 2=787,6, \mathrm{sd}=293, x 2 / \mathrm{sd}=2,68$, RMSEA $=$ $.07, \mathrm{NFI}=.99, \mathrm{CFI}=.91, \mathrm{IFI}=1.00, \mathrm{RFI}=.98, \mathrm{GFI}=.94, \mathrm{AGFI}=.91, \mathrm{SRMR}=.015)$. Cronbachova vrijednost podtestova bila je od .76 do .92 . U ovome istraživanju, unutarnja konzistentnost koeficijenta pouzdanosti za izgaranje uslijed školskih aktivnosti je .83, za izgaranje koje proizlazi iz obitelji .88, zbog osjećaja nedostatnosti u školi .74 te za nedostatak interesa za školu .85. Koeficijent pouzdanosti za cijelu ljestvicu je .80, a Cronbachov alfa-koeficijent .76 .

Skala stavova prema učenju (Scale of Attitudes Toward Learning, Kara, 2010). Da bi se odredili stavovi ispitanika prema učenju, korištena je Skala stavova prema učenju (Kara, 2010). Skala se sastoji od 40 čestica i 4 poddimenzije koje su priroda učenja (7 čestica), očekivanje (9 čestica), jasnoća (11 čestica) i tjeskoba (13 čestica). Cronbachov alfa- 
koeficijent za poddimenzije skale proteže se od .72 do .78. Rezultati faktorske analize ljestvice su sljedeći: KMO = .79, Bartlettov test sferičnosti $=3101,363$, Cronbachov alfa $=.726$. Najavljeni koeficijent varijance je iznad $50 \%$. Koeficijent pouzdanosti ljestvice metodom test-ponovni test je .87. Cronbachov alfa-koeficijent za prikazanu ljestvicu je .88 .

\section{Postupak i obrada podataka}

Od ispitanika su dobivene dozvole za sudjelovanje u ispitivanju te im je objašnjena svrha istraživanja. Ispitanici su dobrovoljno ispunjavali ljestvicu u svojim razredima. Ukupno je 490 ispitanika sudjelovalo u istraživanju, međutim 15 ispitanika nije odgovorilo na čestice prema uputama, a 4 ispitanika odabrala su ekstremne vrijednosti na ljestvici i oni su bili isključeni iz analize. Za ispitivanje korelacije između bodova na skalama Angažman u školi, Stavovi prema školi i Izgaranje u školi, korišten je Pearsonov koeficijent korelacije produkt-moment. Za ispitivanje posredničke uloge stava prema učenju i odnosa između angažmana u školi i izgaranja u školi primijenjena je hijerarhijska regresijska analiza po uzoru na Baron i Kenny (1986). Analize su rađene koristeći SPSS 22.0.

\section{Rezultati}

\section{Deskriptivni podatci i međukorelacije}

Korelacijske vrijednosti dobivene mjernim instrumentima te deskriptivna statistika i Cronbach alfa-vrijednosti prikazane su u tablici 1 .

Analizirajući podatke iz tablice 1 , može se primijetiti značajna korelacija između angažmana u školi i stava prema učenju. Postoji negativna značajna korelacija između izgaranja u školi i angažmana u školi $(r=-.66)$ te stava prema učenju $(r=-.52)$. Nadalje, postoji pozitivan odnos između stava prema učenju i angažmana u školi $(r=.63)$.

\section{Ispitivanje posredničke uloge stava prema učenju i odnosa između izgaranja u školi i angažmana u školi}

Prema stupnjevima modela posredovanja, prvo je potvrđeno da su izgaranje u školi i stav prema učenju negativno povezani $(\beta=.52, t=-16.83, p=.000)$. Nadalje, potvrđeno je da su stav prema učenju i angažman u školi pozitivno povezani $(\beta=.62, t=22.10$, $p=.000)$. U svrhu ispitivanja zadnjega stupnja modela posredovanja primijenjena je hijerarhijska regresijska analiza. Rezultati hijerarhijske regresijske analize pokazali su da je izgaranje $\mathrm{u}$ školi negativno povezano s angažmanom u školi $(\beta=-.66, t=-24.35$, $p<.01)$. Ipak, kada se stav prema školi i izgaranje u školi uvrste u regresijsku analizu, značajnost odnosa između izgaranja u školi i angažmana u školi $(\beta=-.46, t=-16.15$, $p<.01)$ se smanjuje, međutim povezanost između izgaranja u školi i angažmana u školi još je uvijek značajna. Prema Baron i Kenny (1986) predmetni nalaz ukazuje na djelomičnu posredničku ulogu stava prema učenju. Prema rezultatima, može se 
zaključiti da stav prema učenju djelomično posreduje u odnosu između izgaranja u školi i angažmana u školi (Sobel $\mathrm{z}=12.52, \mathrm{p}<.000$ ). Rezultati su prikazani u prikazu 1.

Tablica 1

Prikaz 1.

\section{Diskusija i zaključak}

Cilj ovoga istraživanja je ispitati posredničku ulogu stava prema učenju u odnosu izgaranja u školi i angažmana u školi. Rezultati istraživanja pokazuju da postoji negativna značajna povezanost između izgaranja u školi i angažmana u školi, a stav prema učenju ima posredničku ulogu u odnosu između izgaranja u školi i angažmana u školi kao što je i očekivano. Ovi rezultati ukazuju na to da kada se razine izgaranje u školi smanje, razine angažmana u školi se povećaju, a visoke razine pozitivnoga stava učenika prema učenju utječu na angažman na pozitivan način.

Rezultati su također otkrili važnost stava prema učenju za poboljšanje angažmana u školi. Kako se izgaranje u školi povećava, angažman u školi se smanjuje. Slično je istraživanje provedeno o povezanosti angažmana u školi i izgaranja u školi pokazalo da postoji negativna korelacija između izgaranja u školi i angažmana u školi (Özdemir, 2015; Schaufeli i sur., 2002). Istraživanjem literature nailazimo na slične rezultate te potvrđujemo rezultate ovoga istraživanja. Točnije, ako učenici imaju pozitivan stav prema učenju, njihova razina izgaranja u školi se smanjuje i postaju uspješnija u akademskom postignuću (Bask i Salmela-Aro, 2013; Murberg i Bru, 2003), imaju pozitivne stavove prema školi (Pilkauskaite i sur., 2011), i svoje školsko okruženje doživljavaju pozitivnijim (Salmela i sur., 2008). Istraživanjem koje su proveli Schaufeli i sur. (2002) utvrđeno je da postoji negativna povezanost između akademskoga postignuća i izgaranja u školi i da postoji pozitivna korelacija između pozitivne korelacije između akademskoga postignuća i angažmana u školi. Stoga se može zaključiti da učenici koji više vremena potroše na učenje, postaju uspješniji u školi i prema tome se angažman u školi povećava, a smanjuje se razina izgaranja u školi ako imaju pozitivan stav prema učenju (Wang i sur., 2015).

Podatci dobiveni iz istraživanja moraju se pažljivo interpretirati. Prvo je utvrđeno da je izgaranje u školi negativno povezano sa stavom prema učenju kao što je u istraživanju i pretpostavljeno. Kako se razine izgaranja u školi povećavaju, tako se stav prema učenju smanjuje i negativno utječe na školsko postignuće (Schaufeli i sur., 2002; Yang, 2004). Nadalje, učenici koji su doživjeli izgaranje u školi također imaju i nisku razinu osobne kompetentnosti (Esteve, 2008; Guthrie i sur., 1998). Izgaranje u školi povećava razinu stresa u akademskom postignuću (Murberg i Bru, 2003), što negativno utječe na dobrobit učenika i kao rezultat učenici se doimaju nenaklonjeni aktivnostima učenja (Salmela i Tynkkynen, 2012; Raiziene i sur., 2014;). Kao drugo, utvrđeno je da stav prema učenju pozitivno predviđa angažman u školi. Rezultat da želja za učenjem i pozitivan stav prema učenju povećavaju angažman u školi podudara se $s$ 
drugim istraživanjima. Oni ukazuju na to da učenici s visokom razinom angažmana u školi imaju želju za učenjem te imaju bolji školski uspjeh (Eith, 2005), imaju bolje odnose s učiteljima (Murray i Greenberg, 2000), preuzimaju više odgovornosti u školi (Jenkins, 1995) i sudjeluju u više školskih aktivnosti (Stewart, 2003).

Ograničenja ovoga istraživanja trebala bi se uzeti u obzir kod analize podataka. Prvo, nije pravilno utvrđivati uzročno-posljedičnu povezanost jer istraživanje nije rađeno kao eksperimentalno. Iako modeli strukturnih jednadžbi donose uzročnost, nije moguće izvoditi precizne zaključke o uzročnosti između varijabli jer je ovo istraživanje korelacijsko istraživanje. Ovo istraživanje provedeno je na učenicima iz dvije različite srednje škole unutar okruga Küçükçekmece u Istanbulu s učenicima koji su dobrovoljno sudjelovali u istraživanju. Stoga je važno ponoviti istraživanje i u drugim mjestima sa sličnim skupinama učenika. S obzirom na to da se istraživanjem htjelo dobiti novi model, umjesto testiranja postojećega modela, rezultati daju nova objašnjenja. Stoga se rezultati ne mogu prihvatiti sa sigurnošću sve dok se istraživanje ne ponovi na drugim uzorcima. U istraživanju su korištene skale Stav prema učenju, Izgaranje u školi i Angažman u školi. Rezultati su dobiveni kroz odgovore učenika, a kvalitativna mjerenja nisu rađena. Istraživanje je pokazalo da stav prema učenju ima posredničku ulogu u povezanosti odnosa izgaranja u školi i angažmana u školi. Nadalje, postoji potreba za drugim kognitivnim, afektivnim i društvenim varijablama koje mogu imati posredničku ulogu u odnosu izgaranja u školi i angažmana u školi. Konačno, savjetnicima u školama i stručnjacima savjetuje se da provode istraživanja kako bi poboljšali stav učenika prema učenju te da primjenjuju psihološko-obrazovne programe koji mogu smanjiti razine izgaranja u školi i povećati njihov angažman u školi. 